\title{
AC 2009-837: ALIGNING ENGINEERING EDUCATION INITIATIVES FOR KNOWLEDGE ECONOMIES: OUTCOMES OF THE IFEES GLOBAL ENGINEERING EDUCATION SUMMIT
}

\section{Maria M. Larrondo Petrie, Florida Atlantic University}

Dr. Maria M. Larrondo Petrie is Vice President of the International Federation of Engineering Education Societies, Vice Chair of Engineering for the Americas, Executive Director of the Latin American and Caribbean Consortium of Engineering Institutions, and a Board Member of the Women in Engineering Division and the Minorities in Engineering Division of ASEE. She is Professor of Computer Engineering and Associate Dean of Academic and International Affairs in the College of Engineering and Computer Science at Florida Atlantic University. Her email is petrie@fau.edu

\section{Jose Carlos Quadrado, Instituto Superior de Engenharia de Lisboa}

Dr. Jose Carlos Quadrado is President of the Instituto Superior de Engenharia de Lisboa (ISEL), Portugal. He is Vice President of the International Federation of Engineering Education Societies (IFEES), and served as Co-Chair of the 2008 IFEES Global Engineering Education Summit held in Cape Town, South Africa. He is the President-Elect of the Iberoamerican Engineering Education Society (ASIBEI).

\section{Lueny Morell, Hewlett-Packard}

Lueny Morell is President of the International Federation of Engineering Education Societies (IFEES) and Vice Chair of Engineering for the Americas (EftA). She is the Director of Engineering Education Innovation of HP Labs Open Innovation Office at Hewlett Packard.

\section{Hans Hoyer, American Society for Engineering Education}

Dr. Hans Jürgen Hoyer is the Executive Secretary of the International Federation of Engineering Education Societies (IFEES) and the Director for International Programs and Strategy at the American Society of Engineering Education (ASEE). 


\title{
Aligning Engineering Education Initiatives for Knowledge Economies: Outcomes of the IFEES Global Engineering Education Summit
}

\begin{abstract}
The International Federation of Engineering Education Societies (IFEES) held its second Global Engineering Education Summit in Cape Town, South Africa in October 2008. The goal of the Summit was to begin aligning the initiatives of the engineering education societies, industries and government agencies around the world to maximize impact on knowledge economies. A five hour workshop specially designed by the World Bank Institute was embedded in the two day Summit to assist the leaders in formulating local and global, long and short term action plans. The highly interactive Summit began with policy makers presenting their perspectives, and was followed by short presentations by engineering education societies and industry leaders highlighting initiatives. The initiatives were grouped under an area of focus in the IFEES Strategic Plan: Infrastructure and Accreditation; Research, Development and Entrepreneurship; Student Success; and Lifelong Learning. This paper presents an analysis and summary of the outcomes of the Summit.
\end{abstract}

\section{Introduction}

The International Federation of Engineering Education Societies (IFEES) ${ }^{1}$ was created on the $9^{\text {th }}$ of October 2006 in Rio de Janeiro, Brazil. Within days IFEES joined the Organization of American States (OAS), the American Society of Engineering Education (ASEE), Engineering for the Americas (EftA), the Latin American and Caribbean Consortium of Engineering Institutions (LACCEI), the Asociación Iberoamericana de Instituciones de Enseñanza de Ingeniería (ASIBEI), and the Ibero-American Science and Technology Education Consortium (ISTEC) in signing the Engineering Education Collaboration Agreement for the Americas ${ }^{2}$. IFEES has now grown to 52 member societies (see Appendix A) from academia and industry. It held its First IFEES Global Engineering Education Summit in Istanbul, Turkey in $2007^{3}$. The main outcome of the first Summit, whose theme was Moving from Concept to Action, was the approval of the IFEES 2008-2012 Strategic Plan³ . The Founding President Claudio Borri challenged IFEES members to try to answer the question:

"How can education in Science and Technology help to reduce poverty to boost socioeconomic development and to take the right decisions for a sustainable and environmentally compatible development?"

This question became the cornerstone of this first Strategic Plan and helped delineate the core values of IFEES:

- Promoting engineering education excellence globally

- Supporting IFEES member excellence

- Caring about our communities and our environment

- Promoting culture of community building and strong collaboration among members and other appropriate stake holders

- Fostering cultural awareness and diversity among its stakeholders 
- Cultivating integrity, honesty, work ethics, and social responsibility in the engineering profession

- Promoting capacity building and contributing to the socio-economic development of lesser developed communities

- Acting with integrity, transparency and respect in dealing with members and nonmembers

The IFEES Assembly approved the Strategic $\mathrm{Plan}^{4}$, which determined that

- IFEES will work in close cooperation with national regional organizations from around the globe to influence public policy at the local, national and international levels in support of engineering education, while striving for operational excellence (including IFEES sustainability) and development of its members.

- The IFEES Vision is to foster and enhance the capabilities of an active global community of stakeholders empowered to advance engineering education worldwide.

- The IFEES Mission is to provide a global network to leverage the collective resources of members in fulfilling their individual missions by identifying discussing and advancing common objectives of the Engineering Education community.

- IFEES will focus on initiatives in four Action Areas: Engineering Education Infrastructure; Research, Development and Entrepreneurship; Student Attraction and Success; and Lifelong Learning

\section{7 - 2008 IFEES Initiatives}

The first IFEES initiatives launched in the 2007 IFEES Global Engineering Education Summit in Istanbul focused on building the Engineering Education Infrastructure and on Student Attraction and Success:

1. Initiative to create the Indo-US Collaboration for Engineering Education (IUCEE) led by Krishna Vedula, Dean Emeritus of the University of Massachussetts - Lovell, brought together leaders of engineering education, engineering businesses from India and US, government representatives and World Bank colleagues to create the collaboration. One of its first goals was to design a Summer Faculty Leadership Institute ${ }^{6}$ to be held in 2008.

2. Initiative to create the Global Engineering Deans/Rectors Council $(\text { GEDC })^{7,8}$, led by Dr. Seeram Ramakrishna from the University of Singapore. Dr. Ramakrishna explained the motivation behind this initiative:

"With the backdrop of globalization and rapid technological advancements, there is heightened expectation on engineering colleges to help respective economies to grow and sustain societies. An international forum would be useful to discuss the varied challenges and opportunities faced by engineering colleges around the world and to network and forge collaborations among the colleges." 7

The goals of the GEDC are to:

a. Provide a forum for exchange of information and discussion of experiences, challenges and best practices in leading an engineering school

b. Provide a means for engineering deans to partner in innovation, and collaborate with industry and other stakeholders 
c. Build a network that would support engineering deans to play a leadership role in developing regional and national policy to advance economies

3. Initiative to create a global student organization called Student Platform for Engineering Education Development (SPEED) ${ }^{9}$, led by Nicolò Wojewoda and Julia Ivanova, who collaborated with other student organizations to organize a Global Student Forum ${ }^{10}$.

In October 2008, the Second Global Engineering Education Summit was held in Cape Town, South Africa. The theme was Aligning Engineering Education Initiatives for a Knowledge Economy. This paper presents IFEES progress in its three stated initiatives. It evaluates the format used for the 2008 Summit and outcomes of the 2008 Summit.

\section{IFEES Outcomes 2007-2008}

This section discusses the progress made on the three IFEES initiatives identified in 2007.

\section{IUCEE - Indo-US Collaboration for Engineering Education}

IUCEE aims to identify, promote, catalyze, and add value to assist in the scale up and multiplication of promising practices for collaboration in

- Research and Development

- Curriculum and Technology Enhanced Delivery

- Innovation and Entrepreneurship

- Quality and Accreditation Processes

- Industry Participation

The IUCEE initiative strives to prepare the next generation of engineering faculty in India and the United States, and to dramatically increase the number of collaborations in research and teaching to better prepare engineers for the global economy. The planning phase involved almost 200 academic and business leaders from both countries and resulted in raising close to US\$1M to fund the first Summer Faculty Leadership Institute. The Institute was designed as a series of 23 one-week Train-the-Trainer workshops taught by US faculty members and corporate representatives known for their pedagogical skills. The topics covered general effective teaching techniques as well as best practices teaching in specific engineering disciplines. The workshops were held during a six week period during the Summer 2008 at the InfoSys Technologies' Global Education Center in Mysore India. The 585 Indian faculty participants were selected from a pool of 1400 applicants based on their potential to be trainers in their own colleges and regions. Each typically enrolled in a methodology workshop and a discipline-based workshop. All agreed to lead regional workshop throughout India. The participants had the following profile:

- All participants had at least a Master of Technology or Master of Engineering Degree.

- $25 \%$ had PhDs;

- $75 \%$ has more than 10 years teaching experience;

- $25 \%$ were senior administrators or heads of colleges;

- $24 \%$ were female

- $15 \%$ from AP, $7 \%$ from Gujarat, 26\% from Karnataka; 16\% Maharashtra; $20 \%$ from

Tamil Nadu; and 15\% from other states in India.

- 175 colleges were represented 
As a follow up, the participants have been contacted several times to ensure they are practicing the techniques, are doing outcome based assessment, and are conducting seminars for other faculties in their colleges and regions. Mentoring of participants in technical and academic research has started to occur and has resulted in publications ${ }^{11}$. Over the next five years, IUCEE hopes to cover all the core courses in engineering and computer science and make the resources generated, easily accessible to faculty all over the world. A second Institute is planned for Summer 2009, several academic leaders from other parts of the world will be invited to participated to explore how to adapt the IUCEE model to carry the initiative to other parts of the world.

\section{GEDC - Global Engineering Deans/Rectors Council}

On May 8 and 9, 2008 the Global Engineering Deans/Rectors Council was formed in Paris by engineering education leaders representing prestigious institutions from all continents. The Paris Declaration: Inaugural Statement of the Global Engineering Deans Council ${ }^{12}$ was translated to 13 languages and reproduced. It declaration affirms the commitment to nurture the development of locally pertinent and global engineers, and collaborate in a global scale. It defined the GEDC immediate goals:

- To provide a world-wide forum for exchange of information and discussion of experiences, challenges, and best practices in leading an engineering school.

- To provide a means for engineering deans to partner with one another in curriculum development and innovation, and to collaborate with industry, government, and other stakeholders.

- To build a network that would support engineering deans to play a leadership role in developing regional and national policies to advance economies.

- To participate in the development and maintenance of a global system of quality standards for engineering education.

The GEDC elected Cristina Amon, Dean at the University of Toronto, Canada, was elected GEDC Chair. Hasan Mandal, Dean at Anadolu University was elected Vice Chair. Yong Hoon Lee, Dean of Korea Advanced Institute of Science and Technology was elected Secretary Treasurer. The American Society of Engineering Education hosts the secretariat of both IFEES and GEDC.

\section{SPEED - The Student Platform for Engineering Education Development}

The Global Student Forum (GSF) is a one week event that is organized by students in the format of a series of workshops, discussions, presentations and action plan development sessions that enable them to have a voice and impact on engineering education. At the first GSF in 2006, the concept of the Student Platform for Engineering Education Development (SPEED) was born and has developed over subsequent GSFs. Before the end of the 2008 GSF, the students gathered to write the first draft constitution and bylaws to formalize the organization. SPEED is a global, non-profit student organization of engineering students with the goal of voicing student opinion to create an impact to enrich engineering education curricula worldwide and its effect on society and the environment. A web site has been created ${ }^{9}$. Nicolò Wojoweda, a co-founder of SPEED, is the coordinator of the initiative, and Jennifer DeBoer is representing SPEED within IFEES. 


\section{IFEES 2008 Summit Evaluation, Outcomes and Goals}

The 2008 IFEES Global Engineering Education Summit theme was: The theme was Aligning Engineering Education Initiatives for a Knowledge Economy. The Summit had 6 objectives:

1. Advance understanding of the relationship between engineering education and knowledge economies

2. Share successful initiatives and best practices, and how they can be adapted to the developing world, with the goal of catalyzing alliances to align initiatives and leverage resources to support knowledge economies

3. Develop local, global, short term and long term action items, relevant to the participant's organization or sector that advance engineering education and knowledge economies.

4. Bring together global leaders from relevant sectors and provide opportunities to network to identify action items that advance common objectives, and to form alliances and working groups to advance these and report outcomes in the next summit

5. Understand the needs and best practices/successes of IFEES member organizations (primarily engineering education associations) in order to initiate a dialogue that will enable IFEES to develop focused strategies to support development of this members in a focused sensible way (identifying needs of both developed and developing world engineering education associations)

6. Understanding the engineering education situation in Africa and how IFEES and engineering education can support/help.

A key session to meet these objectives, was a five-hour workshop that was jointly developed by the World Bank Institute and IFEES: Engineering Education in the Knowledge Economy, aimed at giving a deeper understanding of the concept of a knowledge economy in theory and in practice, specifically how engineering education can be better structured to support this economy in the context of the widely varied regional and sector perspectives. In particular, initiatives and perspectives from Africa and India were highlighted.

With this foundation, some sessions were designed to reach out to stakeholders to understand initiatives, perspectives, challenges and expectations; while others used round tables designed to reach in to communicate to IFEES members to identify initiatives that IFEES should endorse and help IFEES and the participants define long and short term, global and local action items for the coming year.

The Summit began with the perspectives of policy makers from Africa, China, Russia, and the U.S. speaking on The Role of Engineering Education and Innovation in Knowledge Economies. Panels highlighting engineering education initiatives were grouped into 3 sessions organized by the IFEES focus area: Engineering Education Infrastructure; Student Attraction and Success; and Research, Development, Entrepreneurship and Innovation.

When asked how the Summit met these 6 objectives the participants responded as shown in Table 1 and Figure 2. According to the evaluation $79 \%$ of the respondents were either Very Satisfied (28\%) or Satisfied (52\%) that they had gained a deeper understanding of the relationship between engineering education and knowledge economies, and $75 \%$ of the respondents being Very Satisfied (39\%) or Satisfied (36\%) indicating the Summit met objective 
number 4 related to providing opportunities to network and form alliances to identify action items and form working groups.

Table 1. Participant Responses to Satisfaction that the Objectives were met IFEES - International Federation of Engineering Education Societies 2008 Short Term Summit Objectives and Evaluation

\section{Evaluation / Scale}

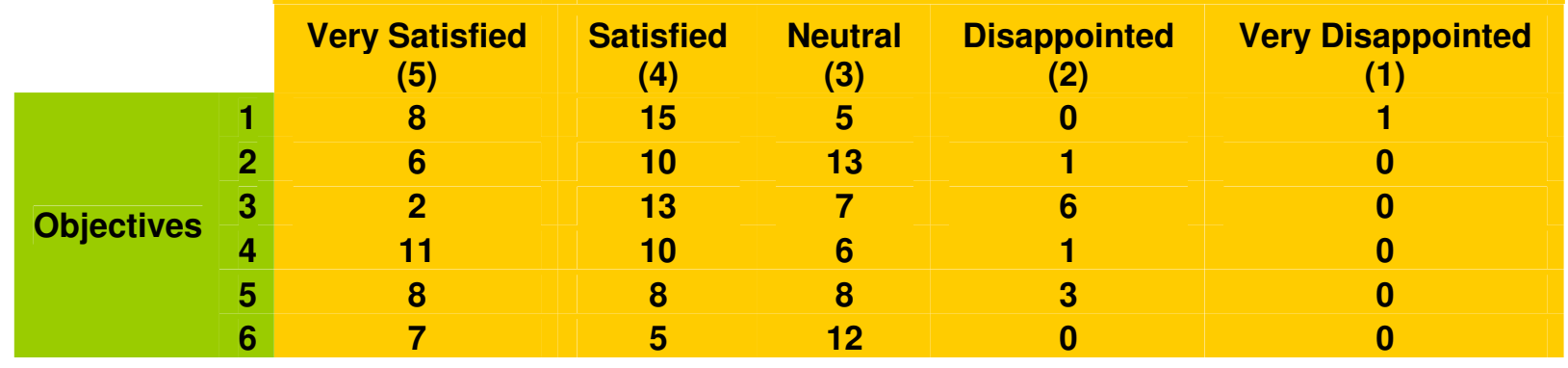

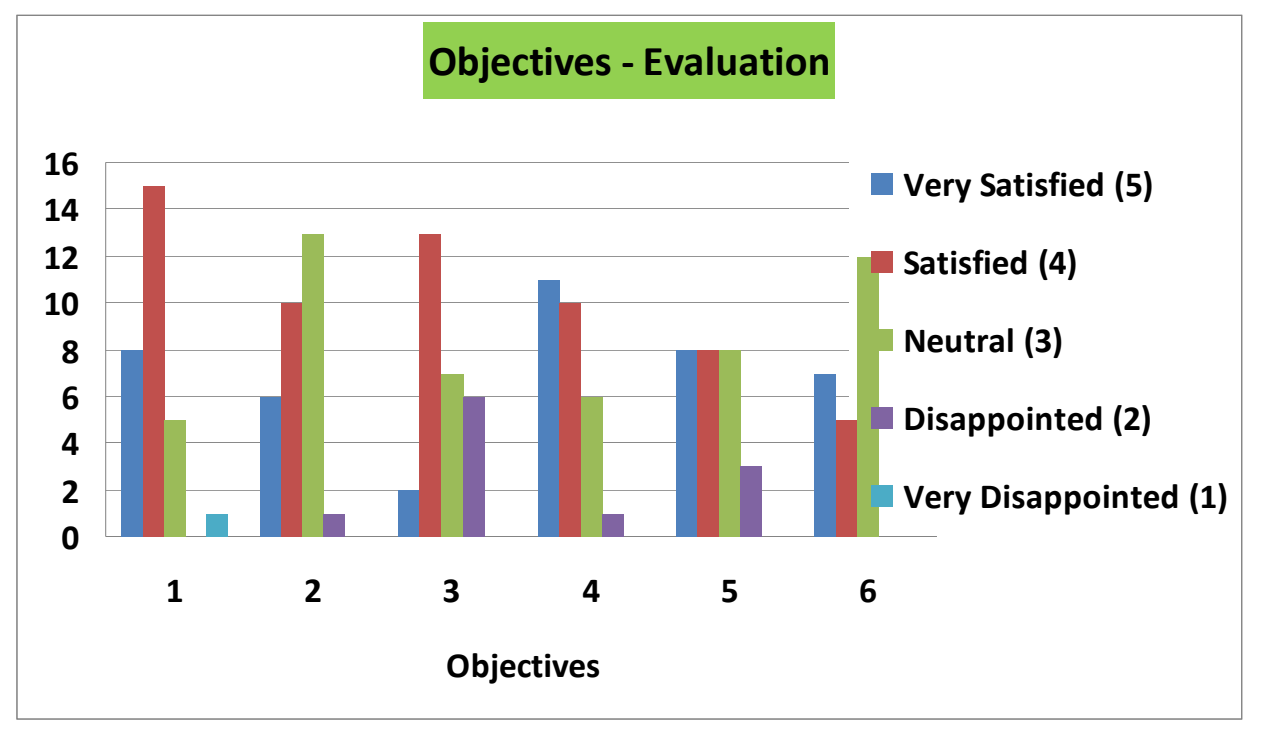

Figure 2. Histogram Summary of Participants Satisfaction Objectives were met

\section{IFEES Summit Enhanced Interaction Format: Planned but not realized}

The 2008 Summit was designed to begin with presentations from Ministers and Government Agency representatives from around the world, followed by a period of interaction. There were 3 panels featuring very brief spotlights on initiatives centered on 3 of the action areas of the IFEES Strategic Plan, each panel followed by interaction and a session with round tables focusing on regions or special topics. The format was designed to have very brief presentations with time for discussion providing enhanced interactions and networking. Because of logistics and transportation problems the first day of the Summit started about 1 hour late, which eliminated much of the interaction time of the morning. The afternoon featured the 5 hour World Bank Workshop, which had its full interaction but the venue was set up in an auditorium with fixed chairs, which was not optimal for communicating in groups. The second day of the 
Summit the venue was changed to avoid the challenges of the first location, this caused delays beginning the event and caused elimination of a significant portion of the planned enhanced interaction. Part of the evaluation asked a question regarding the design of the enhanced interaction and its effectiveness. Table 2 and Figure 3 show the low response and the frustration of the limited interaction caused by the logistic challenges. It is important to note that there was no Enhanced Interaction, except in the World Bank Workshop, since most had to be eliminated. The responses indicate the participants would like more interaction.

Table 2. Responses to Satisfaction with Enhanced Interaction Format The Summit - Enhaced interaction

\begin{tabular}{|c|c|c|c|c|c|c|}
\hline & & $\begin{array}{l}\text { Very Satisfied } \\
\text { (5) }\end{array}$ & $\begin{array}{l}\text { Satisfied } \\
\text { (4) }\end{array}$ & $\begin{array}{l}\text { Neutral } \\
\text { (3) }\end{array}$ & $\begin{array}{c}\text { Disappointed } \\
\text { (2) }\end{array}$ & $\begin{array}{l}\text { Very Disappointed } \\
\text { (1) }\end{array}$ \\
\hline \multirow{3}{*}{$\begin{array}{c}\text { Summit } \\
\text { Interactions }\end{array}$} & $\begin{array}{c}\text { A } \\
\left({ }^{*}\right)\end{array}$ & 3 & 14 & 3 & 3 & 1 \\
\hline & $\begin{array}{c}\text { B } \\
(* *)\end{array}$ & 4 & 9 & 5 & 3 & 0 \\
\hline & $\underset{(* \star \star)}{\mathbf{C}}$ & 8 & 10 & 6 & 0 & 0 \\
\hline
\end{tabular}

\section{$\left.{ }^{\star}{ }^{\star}\right)$ Panels of many speakers presenting very short presentations centered on initiatives}

$\left.{ }^{(* *}\right)$ Embedded Workshop to provide a knowledge base, best practices, and action outcomes

$\left.{ }^{* * *}\right)$ Round Tables on special topics

Figure 3. Histogram of Responses to Enhanced Interaction Format

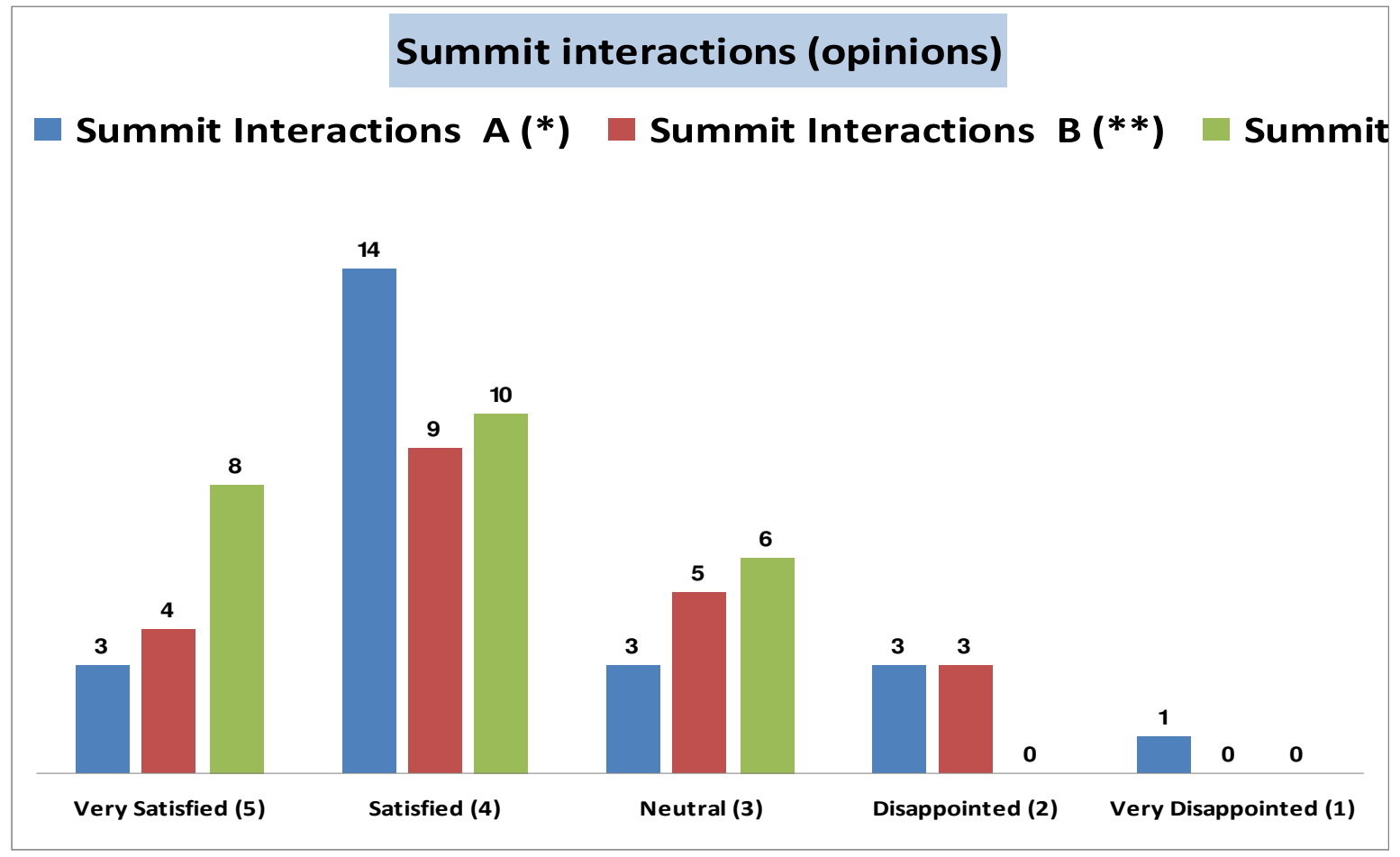


There were two open questions in the evaluation survey. The questions and the responses to them are shown in Table 3.

Table 3. Evaluation Responses to Open Questions

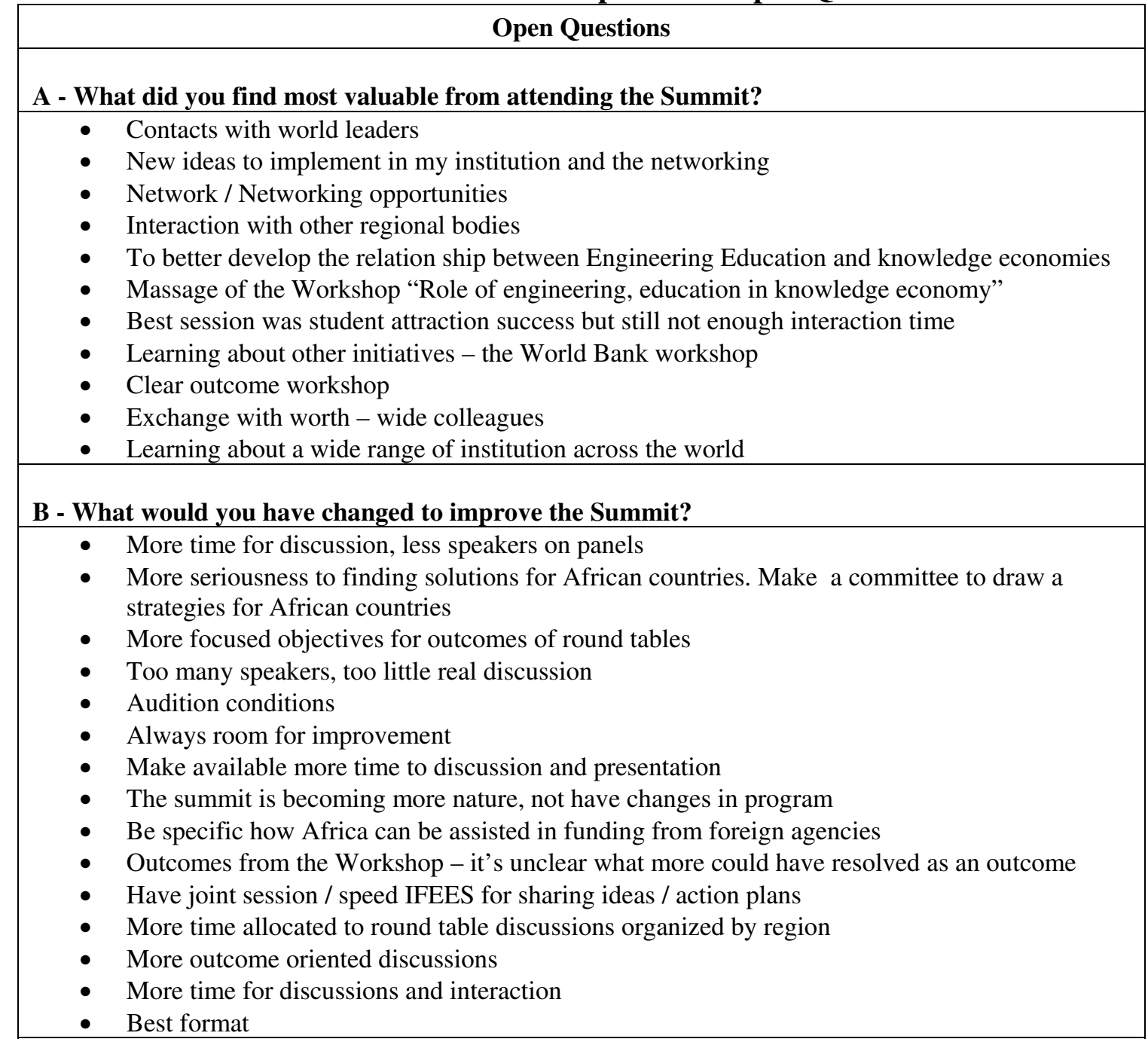

As part of the Summit evaluation, the participants were asked to identify action items that resulted from participation in the Summit that they would take back to their organizations for possible implementation. They were asked to categorize them as short term vs long term and local vs regional/global. Twenty one individual volunteered their action items, all but one identifying themselves by name and email for follow-up so we can report progress at the next Summit. The action items came from universities, engineering education societies, accreditation agencies from 10 different countries: Australia, Canada, Europe, India, Malawi, Nigeria, Portugal, Romania, South Africa, and USA. Individuals identified a total of 25 Long Term Local Action Items, 29 Long Term Global/Regional Action Items, 19 Short Term Local Action Items and 23 Short Term, Regional/Global Action Items. A total of 96 action items were submitted and being taken back to their organization for possible implementation. Table 4 lists the responses. Appendix A contains a list of acronyms for members of IFEES for reference. 
Table 4. Long Term and Short Term, Local and Regional / Global Action Items

\begin{tabular}{|c|c|c|c|c|c|}
\hline & \multirow[b]{2}{*}{ Participants } & $\mathbf{A}$ & B & $\mathbf{C}$ & D \\
\hline & & Long Term LocalAction Items & $\begin{array}{l}\text { Long Term Regional / } \\
\text { Global Action Items }\end{array}$ & $\begin{array}{c}\text { Short Term Local } \\
\text { Action Items }\end{array}$ & $\begin{array}{l}\text { Short Term Regional / } \\
\text { Global Action Items }\end{array}$ \\
\hline \multirow[b]{2}{*}{1} & Country: USA & \multirow{2}{*}{$\begin{array}{l}\text { Begin potential collaboration } \\
\text { with UCT on DLMs for } \\
\text { Engineering Education }\end{array}$} & \multirow{2}{*}{$\begin{array}{l}\text { Large Scale Center } \\
\text { Proposal for Globalizing } \\
\text { Engineering Education }\end{array}$} & \multirow{2}{*}{$\begin{array}{l}\text { Begin potential } \\
\text { collaboration with UCT } \\
\text { on DLMs for } \\
\text { Engineering Education }\end{array}$} & \multirow{2}{*}{$\begin{array}{l}\text { Large Scale Center } \\
\text { Proposal for Globalizing } \\
\text { Engineering Education }\end{array}$} \\
\hline & $\begin{array}{l}\text { Organization: } \\
\text { University }\end{array}$ & & & & \\
\hline \multirow[b]{2}{*}{2} & Country: USA & & & & Create resource hub \\
\hline & $\begin{array}{l}\text { Organization: } \\
\text { Service } \\
\text { Learning } \\
\text { Organization } \\
\end{array}$ & & & & $\begin{array}{l}\text { governing campuses } \\
\text { activities (by engineers) }\end{array}$ \\
\hline \multirow[b]{2}{*}{3} & $\begin{array}{l}\text { Country: } \\
\text { Nigeria }\end{array}$ & \multirow{2}{*}{$\begin{array}{l}\text { Sensitize my local university } \\
\text { administrators, and funding } \\
\text { agencies on the need to develop } \\
\text { engineering education }\end{array}$} & \multirow{2}{*}{$\begin{array}{l}\text { Apply to World Bank } \\
\text { and other funding } \\
\text { agencies to assist with } \\
\text { DLM unit acquisition } \\
\text { and online lab. facilities }\end{array}$} & \multirow{2}{*}{$\begin{array}{l}\text { Sensitize my local } \\
\text { university } \\
\text { administrators, and } \\
\text { funding agencies on the } \\
\text { need to develop } \\
\text { engineering education }\end{array}$} & \multirow{2}{*}{$\begin{array}{l}\text { Apply to world bank and } \\
\text { other funding agencies to } \\
\text { assist with DLM unit } \\
\text { acquisition and online lab } \\
\text { facilities }\end{array}$} \\
\hline & $\begin{array}{l}\text { Organization: } \\
\text { University }\end{array}$ & & & & \\
\hline \multirow[b]{2}{*}{4} & $\begin{array}{l}\text { Country: } \\
\text { Portugal }\end{array}$ & \multirow{2}{*}{$\begin{array}{l}\text {-EUR-ACE Accreditation for } \\
\text { our courses } \\
\text {-"Develop" a new type of } \\
\text { engineer } \\
\text {-Workshops about: } \\
\text { Innovation / } \\
\text { Entrepreneurship / } \\
\text { Leadership }\end{array}$} & \multirow{2}{*}{$\begin{array}{l}\text {-Social } \\
\text { Entrepreneurship } \\
\text { as a goal } \\
\text { - Implementation of } \\
\text { problem based learning } \\
\text { courses } \\
\text {-Mobility of students } \\
\text { - Cooperation with } \\
\text { Africa } \\
\text { and Ibero American }\end{array}$} & \multirow{2}{*}{$\begin{array}{l}\text {-Sustainable project } \\
\text { involving students and } \\
\text { professors } \\
\text { - BEST courses for } \\
\text { students } \\
\text { - On line resources }\end{array}$} & \multirow{2}{*}{$\begin{array}{l}\text { - Board of European } \\
\text { students of technology } \\
\text { (BEST) involving } \\
\text { students association } \\
\text {-Integrating } \\
\text { international } \\
\text { engineering education } \\
\text { consortiums }\end{array}$} \\
\hline & $\begin{array}{l}\text { Organization: } \\
\text { University }\end{array}$ & & & & \\
\hline \multirow[b]{2}{*}{6} & Country: USA & & \multirow{2}{*}{$\begin{array}{l}\text { - Sustainability } \\
\text { competition }\end{array}$} & & \multirow{2}{*}{$\begin{array}{l}\text { Link AEEA with ACE } \\
\text { (American Council of } \\
\text { Education) }\end{array}$} \\
\hline & $\begin{array}{l}\text { Organization: } \\
\text { Global } \\
\text { internet hub }\end{array}$ & & & & \\
\hline \multirow[b]{2}{*}{7} & $\begin{array}{l}\text { Country: } \\
\text { Canada and } \\
\text { Malawi } \\
\end{array}$ & \multirow{2}{*}{$\begin{array}{l}\text { Implement initiatives to create a } \\
\text { service learning opportunities } \\
\text { for Malawian engineering } \\
\text { students and to work with the } \\
\text { university of Malawi to create a } \\
\text { forum for industry university } \\
\text { collaborations }\end{array}$} & & \multirow[t]{2}{*}{$\begin{array}{l}\text { Create a forum for } \\
\text { industry university } \\
\text { collaborations }\end{array}$} & \\
\hline & $\begin{array}{l}\text { Organization: } \\
\text { Service } \\
\text { Learning } \\
\text { Organization } \\
\end{array}$ & & & & \\
\hline \multirow[b]{2}{*}{8} & Country: USA & & \multirow[b]{2}{*}{$\begin{array}{l}\text { - Determine } \\
\text { applicability } \\
\text { of "changing the } \\
\text { conversation" } \\
\text { internationally } \\
\text { - Work with SPEED } \\
\text { - Develop strategies for } \\
\text { implementation } \\
\text { - work with / SPEED } \\
\text { IFEES GDC }\end{array}$} & & \\
\hline & $\begin{array}{l}\text { Organization: } \\
\text { Engineering } \\
\text { education } \\
\text { society }\end{array}$ & & & & \\
\hline \multirow[b]{2}{*}{9} & Country: ? & & & \multirow{2}{*}{$\begin{array}{l}\text { Make a study involving } \\
\text { engineering education } \\
\text { development and social } \\
\text { and economic } \\
\text { development }\end{array}$} & \\
\hline & $\begin{array}{l}\text { Organization: } \\
\text { ? }\end{array}$ & & & & \\
\hline \multirow{2}{*}{$\begin{array}{l}1 \\
0\end{array}$} & Country: USA & \multirow{2}{*}{$\begin{array}{l}\text { - HS Program built from } \\
\text { Soyster's PPT stack }\end{array}$} & \multirow{2}{*}{$\begin{array}{l}\text { HS or college student } \\
\text { competition sustainable } \\
\text { engineering }\end{array}$} & & \\
\hline & $\begin{array}{l}\text { Organization: } \\
\text { Industry }\end{array}$ & & & & \\
\hline \multirow[b]{2}{*}{$\begin{array}{l}1 \\
1\end{array}$} & $\begin{array}{l}\text { Country: } \\
\text { Europe }\end{array}$ & & \multirow{2}{*}{$\begin{array}{l}\text { Benchmarking and } \\
\text { interacting with other } \\
\text { international } \\
\text { accreditation systems }\end{array}$} & & \multirow{2}{*}{$\begin{array}{l}\text { Contacts with countries + } \\
\text { HEE associations outside } \\
\text { Europe to foster } \\
\text { accreditation }\end{array}$} \\
\hline & $\begin{array}{l}\text { Organization: } \\
\text { Accreditation } \\
\text { Agency }\end{array}$ & & & & \\
\hline 1 & $\begin{array}{l}\text { Country: } \\
\text { Australia }\end{array}$ & $\begin{array}{l}\text {-Importance of benchmarking / } \\
\text { understanding accreditation }\end{array}$ & $\begin{array}{l}\text { - International } \\
\text { competitions on }\end{array}$ & & \\
\hline 2 & $\begin{array}{l}\text { Organization: } \\
\text { Engineering }\end{array}$ & $\begin{array}{l}\text { systems with ability to manage } \\
\text { national needs and guarantee }\end{array}$ & $\begin{array}{l}\text { sustainability (links to } \\
\text { EWB?) }\end{array}$ & & \\
\hline
\end{tabular}




\begin{tabular}{|c|c|c|c|c|c|}
\hline & $\begin{array}{l}\text { Education } \\
\text { Organization }\end{array}$ & $\begin{array}{l}\text { future change and improvement } \\
\text {-Need to encompass } \\
\text { "engineering technologists" as } \\
\text { well as engineers in future } \\
\text { thinking on engineers education } \\
\text { for sustainable development }\end{array}$ & $\begin{array}{l}\text { - Importance of real } \\
\text { Engineering Education } \\
\text { Research and } \\
\text { development of Faculty } \\
\text { to understate it }\end{array}$ & & \\
\hline \multirow[b]{2}{*}{$\begin{array}{l}1 \\
3\end{array}$} & Country: India & \multirow{2}{*}{$\begin{array}{l}\text { To develop a network with as } \\
\text { many countries by sharing best } \\
\text { practices and help each other to } \\
\text { adopt these by being partner to } \\
\text { all }\end{array}$} & \multirow[b]{2}{*}{$\begin{array}{l}\text { - Attend IFEES - APRC } \\
\text { in } \\
\text { India } \\
\text { - Make more of our } \\
\text { students attend } \\
\text { regional } \\
\text { meetings } \\
\text { - Help students to pick } \\
\text { up } \\
\text { real problems in not } \\
\text { only } \\
\text { their local countries } \\
\text { but } \\
\text { also in other countries }\end{array}$} & \multirow{2}{*}{$\begin{array}{l}\text { - try to get and keep } \\
\text { connected with people } \\
\text { with whom I met }\end{array}$} & \multirow{2}{*}{$\begin{array}{l}\text { - Help students to pick } \\
\text { up real problems in not } \\
\text { only in their local } \\
\text { countries but also in } \\
\text { other countries as well }\end{array}$} \\
\hline & $\begin{array}{l}\text { Organization: } \\
\text { University }\end{array}$ & & & & \\
\hline \multirow[b]{2}{*}{$\begin{array}{l}1 \\
4\end{array}$} & $\begin{array}{l}\text { Country: } \\
\text { South Africa } \\
\end{array}$ & \multirow{2}{*}{$\begin{array}{l}\text { Develop student service module } \\
\text { for all engineering students at } \\
\text { my university }\end{array}$} & \multirow{2}{*}{$\begin{array}{l}\text { - Develop action plan } \\
\text { and } \\
\text { implement it for my } \\
\text { organization } \\
\text { - Round table was very } \\
\text { helpful in this regard }\end{array}$} & \multirow{2}{*}{$\begin{array}{l}\text { Liaise with Bob } \\
\text { Hawkings (World Bank } \\
\text { - Africa Initiatives } \\
\text { coordinator) student } \\
\text { service projects }\end{array}$} & \multirow[t]{2}{*}{$\begin{array}{l}\text { Further promotion of aims } \\
\text { of my organization }\end{array}$} \\
\hline & $\begin{array}{l}\text { Organization: } \\
\text { Engineering } \\
\text { Education } \\
\text { Association } \\
\text { and University } \\
\end{array}$ & & & & \\
\hline \multirow[b]{2}{*}{$\begin{array}{l}1 \\
5\end{array}$} & $\begin{array}{l}\text { Country: } \\
\text { Nigeria }\end{array}$ & \multirow[b]{2}{*}{$\begin{array}{l}\text { - Restructuring university } \\
\text { engineering program for } \\
\text { service to humanity } \\
\text { - Strengthen the African } \\
\text { regions local AEEA for } \\
\text { actions } \\
\text { - Government / industries / } \\
\text { educators - forum to be } \\
\text { establish for continuous } \\
\text { support in engineering } \\
\text { education }\end{array}$} & \multirow[b]{2}{*}{$\begin{array}{l}\text { - AEEA to get } \\
\text { government } \\
\text { attention on } \\
\text { engineering } \\
\text { education } \\
\text {-AEEA should get a } \\
\text { strong } \\
\text { regional voice } \\
\text { - Initiate internal } \\
\text { funding } \\
\text { grants }\end{array}$} & \multirow[b]{2}{*}{$\begin{array}{l}\text { - Nigeria should be } \\
\text { informed that she may } \\
\text { remains in poverty } \\
\text { unless she is prepared } \\
\text { to do what rich } \\
\text { countries have done } \\
\text { - Faculties in } \\
\text { engineering should } \\
\text { verify students projects } \\
\text { to ensure conformity } \\
\text { with } 21^{\text {st century }} \\
\text { challenges } \\
\text { - Presidents of } \\
\text { universities should } \\
\text { involve business men } \\
\text { in to discussions to } \\
\text { innovate engineering } \\
\text { educations } \\
\text { - Developing Nigeria } \\
\text { Engineering } \\
\text { Educations Associations }\end{array}$} & \multirow[b]{2}{*}{$\begin{array}{l}\text { - Attract area } \\
\text { memberships } \\
\text { - Encourage IFEES } \\
\text { membership from } \\
\text { Africa } \\
\text { - Involve more Africa } \\
\text { Presidents in program } \\
\text { area to promote } \\
\text { engineering education } \\
\text { - Support Africans } \\
\text { participants with } \\
\text { sponsorship to attend } \\
\text { engineering educations } \\
\text { programs } \\
\text { - Localizing AEEA }\end{array}$} \\
\hline & $\begin{array}{l}\text { Organization: } \\
\text { University }\end{array}$ & & & & \\
\hline \multirow[b]{2}{*}{$\begin{array}{l}1 \\
6\end{array}$} & $\begin{array}{l}\text { Country: } \\
\text { Nigeria }\end{array}$ & \multirow{2}{*}{$\begin{array}{l}\text { - Strengthen the AEEA in } \\
\text { Africa } \\
\text {-Government involvement in } \\
\text { Africa } \\
\text { - Link AEEA to industry }\end{array}$} & \multirow{2}{*}{$\begin{array}{l}\text { - Strong regional AEEA } \\
\text { - Strong government } \\
\text { involvement } \\
\text { - Strong industry } \\
\text { involvement }\end{array}$} & \multirow{2}{*}{$\begin{array}{l}\text { - Organize national } \\
\text { conferences } \\
\text { - Encourage } \\
\text { collaboration. } \\
\text { - Publicize AEEA } \\
\text { activities } \\
\end{array}$} & \multirow{2}{*}{$\begin{array}{l}\text { - Regional meetings } \\
\text { - Collaborations } \\
\text { - Publications }\end{array}$} \\
\hline & $\begin{array}{l}\text { Organization: } \\
\text { University }\end{array}$ & & & & \\
\hline \multirow[b]{2}{*}{$\begin{array}{l}1 \\
7\end{array}$} & $\begin{array}{l}\text { Country: } \\
\text { Romania } \\
\end{array}$ & & \multirow{2}{*}{$\begin{array}{l}\text { - Promote IFEES among } \\
\text { other student } \\
\text { organizations that we } \\
\text { interact with } \\
\text { - Help creating } \\
\text { networks } \\
\text { student leaders across } \\
\text { Europe for cooperation } \\
\text { and information } \\
\text { exchange }\end{array}$} & & \multirow{2}{*}{$\begin{array}{l}\text { - Provide ideas to other } \\
\text { student organizations } \\
\text { - Share best practices }\end{array}$} \\
\hline & $\begin{array}{l}\text { Organization: } \\
\text { European } \\
\text { Student } \\
\text { Organization }\end{array}$ & & & & \\
\hline \multirow[b]{2}{*}{$\begin{array}{l}1 \\
8\end{array}$} & $\begin{array}{l}\text { Country: } \\
\text { Nigeria }\end{array}$ & \multirow{2}{*}{$\begin{array}{l}\text { Provide an avenue for } \\
\text { information, resources which } \\
\text { include internet resources } \\
\text { sharing }\end{array}$} & \multirow{2}{*}{$\begin{array}{l}\text { Make available internet } \\
\text { programs, and resources } \\
\text { for enhanced teaching } \\
\text { and learning already } \\
\text { developed in the }\end{array}$} & \multirow{2}{*}{$\begin{array}{l}\text { Localize IFEES to } \\
\text { institutions let every } \\
\text { university have a local } \\
\text { IFEES body }\end{array}$} & \multirow{2}{*}{$\begin{array}{l}\text { Provide a forum for } \\
\text { revision of curriculum } \\
\text { engineering, particularly } \\
\text { with the needs of African } \\
\text { industry }\end{array}$} \\
\hline & $\begin{array}{l}\text { Organization: } \\
\text { University }\end{array}$ & & & & \\
\hline
\end{tabular}




\begin{tabular}{|c|c|c|c|c|c|}
\hline & & & $\begin{array}{l}\text { developed nation to } \\
\text { African in particular } \\
\text { through the internet }\end{array}$ & & \\
\hline & $\begin{array}{l}\text { Country: } \\
\text { Nigeria }\end{array}$ & \multirow{2}{*}{$\begin{array}{l}\text { - Engineering Education } \\
\text { Curriculum to be revised to meet } \\
\text { the challenges of the } 21^{\text {st }} \text { century } \\
\text { and the needs of the immediate } \\
\text { society } \\
\text { - To improve teaching/learning } \\
\text { in engineering education through } \\
\text { the use of hands on } \\
\text { classroom/laboratory facilities }\end{array}$} & \multirow[b]{2}{*}{$\begin{array}{l}\text { - Global Engineering } \\
\text { Education Societies to } \\
\text { coverage periodically to } \\
\text { harmonize } \\
\text { ideas/programs to } \\
\text { bridge groups in Global } \\
\text { Engineering Education } \\
\text { for Social, Economic } \\
\text { and infrastrural } \\
\text { development }\end{array}$} & \multirow[b]{2}{*}{$\begin{array}{l}\text { - Accreditation of } \\
\text { Engineering Education } \\
\text { programs to reflect the } \\
\text { needs of the societal } \\
\text { growth } \\
\text { - Research and } \\
\text { development activities } \\
\text { of engineering base to } \\
\text { be funded by all } \\
\text { stakeholders (e.g. } \\
\text { government, companies) }\end{array}$} & \multirow[b]{2}{*}{$\begin{array}{l}\text { - Regional/global } \\
\text { engineering societies to } \\
\text { promote activities in } \\
\text { African countries on } \\
\text { engineering education } \\
\text { - AEEA to collaborate with } \\
\text { Global Engineering } \\
\text { Organizations to achieve } \\
\text { set objectives in terms of } \\
\text { awareness and funding of } \\
\text { activities } \\
\text { - To assess funds from } \\
\text { funding global } \\
\text { organizations/agencies to } \\
\text { promote engineering } \\
\text { education }\end{array}$} \\
\hline $\begin{array}{l}1 \\
9\end{array}$ & $\begin{array}{l}\text { Organization: } \\
\text { University }\end{array}$ & & & & \\
\hline & $\begin{array}{l}\text { Country: } \\
\text { Europe }\end{array}$ & \multirow{2}{*}{$\begin{array}{l}\text { - Create an "European } \\
\text { Engineering Deans Council" } \\
\text { (promotion by SEFI) }\end{array}$} & \multirow[b]{2}{*}{$\begin{array}{l}\text { - Project proposal for a } \\
\text { Global Thematic } \\
\text { Network } \\
\text { on Education } \\
\text { Engineering } \\
\text { with participation from } \\
\text { all } \\
\text { regions } \\
\text { - To promote } \\
\text { comparison } \\
\text { studies between } \\
\text { different } \\
\text { quality } \\
\text { - Ass. and Accreditation } \\
\text { Systems } \\
\end{array}$} & & \\
\hline $\begin{array}{l}2 \\
0\end{array}$ & $\begin{array}{l}\text { Organization: } \\
\text { Engineering } \\
\text { Education } \\
\text { Society }\end{array}$ & & & & \\
\hline & $\begin{array}{l}\text { Country: } \\
\text { Canada }\end{array}$ & \multirow[b]{2}{*}{$\begin{array}{l}\text { - Follow up n some } \\
\text { (course/curriculum) ideas } \\
\text { for implementation at my } \\
\text { university } \\
\text { - Inspired to work harder to } \\
\text { make my colleagues at home } \\
\text { aware of the importance of } \\
\text { sustainability, and to } \\
\text { incorporate it in their work } \\
\text { - Inspired to convey to my } \\
\text { colleagues with modern } \\
\text { student can and to figure out } \\
\text { I can better tend to these } \\
\text { students. } \\
\text { - Will maintain contact with } \\
\text { African colleagues and help } \\
\text { link AHED and help fill } \\
\text { possible vacancies in } \\
\text { universities in African } \\
\text { countries }\end{array}$} & & & \\
\hline $\begin{array}{l}2 \\
1\end{array}$ & $\begin{array}{l}\text { Organization: } \\
\text { University and } \\
\text { Higher } \\
\text { Education } \\
\text { Society }\end{array}$ & & & & \\
\hline
\end{tabular}

\section{Round Table Results}

The Summit concluded with Round Tables of Regional or Special Interests, with one table being open for initiatives proposed by member organizations outside these areas. The results of initiatives or action items for each table were as follows:

\section{Group 1. Accreditation}

- led by Iring Wasser (ASIIN), Hasan Mandal (MDTK, GEDC)

- Promoting a wider understanding of accreditation 
- Benchmarking system training of Educators and Accreditors

- Overlap with Existing Systems

- Accreditation is for Q\&A and Recognition but it should serve to facilitate mobility of graduates and students

Group 2. Africa

- led by Funso Falade (AEEA) and Duncan Fraser (AEEA)

- Strengthening AEEA

- Connecting its local industry and government

- Identify and connect with funding agencies within and outside region

- Results of governments in provisioning of infrastructure and the enabling environment for industry-academia to work

- Making the curriculum relevant to industry need

Group 3. Americas

- led by Maria Larrondo Petrie (LACCEI, UPE), Ramiro Jordan (ISTEC) and Jose Carlos Quadrado (ASIBEI)

- Conduct an IFEES Americas Regional Summit

- Collaborators: Signers of the Rio 2005 Engineering Education Collaboration for the Americas (IFEES, ASIBEI, OAS, LACCEI, ISTEC, ASEE, EftA)

- Goal - influence decision makers in S\&T

- Themes - Investments \& Incentives for S\&T, IP, Visa-Mobility, Sustainability, Social Responsibility

Group 4. Asia-Pacific

- led by Nitte R. Shetty (ISTE)

- Conduct an IFEES Asia Pacific Regional Summit in December 2008

\section{Group 5. Student}

- led by Julia Ivanova (SPEED), Adriana Garboan (BEST), Nicolò Wojewoda (SPEED), and Jennifer DeBoer (SPEED)

- Overarching umbrella for populating engineering curriculum with sustainability

- Develop projects focused on:

- Greening Campuses -create materials and resources for adaptation. Champion: ESW

- Identify leverage points for creating partnerships among stakeholders - Student Faculty - Industry

Champion: IFEES - SPEED

- Create a new competition around sustainability Champions: global.hub.org (Purdue), Mathworks, Autodesk (EMEA)

\section{Group 6. Member Suggested Initiatives}

- led by Lueny Morell (Hewlett-Packard), Claudio Borri (SEFI), and Yuri Petrovich Pokholkov (RAEE)

- Support current initiatives of global engineering education accreditation agreements

- Establish a fund to finance the mobility of faculty, students and managers

- Establish a Leadership Institute for Academic Administrators/Managers 


\section{Conclusion and Future Directions}

Despite many challenges, the collaboration and efforts of IFEES members achieved major objectives and set even higher goals. Even though logistical problems impacted the planned enhanced interaction in a negative way, there were significant number of responses to development of action items, both long term and short term, and local as well as regional/global. Progress on the long and short term action plans put forth in the 2008 Summit will examined during the Third IFEES Global Engineering Education Summit ${ }^{13,14}$ that will take place May 1923, 2009 in St. Petersburg, Russia. For more information and report of on ongoing initiatives see the IFEES web pages ${ }^{14}$.

\section{References}

1. Lueny Morell, Claudio Borri, Sarah Rajala, Seeram Ramakrishna, Jose Carlos Quadrado, Maria M. Larrondo Petrie, Duncan Fraser, Bruno Laporte, Adriana Garboan, Xavier Fouger, Hans J. Hoyer, "Engineering Education Societies Becoming Global: The Evolving Development of the International Federation of Engineering Education Societies (IFEES)," in Proceedings of the $115^{\text {th }}$ Annual American Society for Engineering Education Conference and Exposition (ASEE2008), Pittsburgh, Pennsylvania, USA, 21-25 June 2008. Reprinted in Proceedings of the $7^{\text {th }}$ ASEE Global Colloquium on Engineering Education, Cape Town, South Africa, 19-23 October 2008. Reprinted in Proceedings of the World Engineering Congress (WEC2008), Brasilia, Brasil, 2-6 December 2008.

2. Maria M. Larrondo Petrie, Clement Sankat and Roberto Loran, “The Turabo Declaration and the Engineering Education Capability Maturity Model: LACCEI Initiatives to improve Latin American and Caribbean Engineering Program Accreditation and Recognition," in Proceedings of the $114^{\text {th }}$ Annual American Society for Engineering Education Conference and Exposition (ASEE 2007), Honolulu, Hawaii, USA, 24-27 June 2007. Reprinted in Proceedings of the $6^{\text {th }}$ ASEE Global Colloquium on Engineering Education, Istanbul, Turkey, 1-4 October 2007.

3. First IFEES Global Engineering Education Summit, Istanbul, Turkey, 30 September - 1 October 2007. http://www.ifees.net/activities/upload/ifees-program-260907.pdf

4. IFEES Strategic Plan 2008-2012. http://www.ifees.net/publications/documents/ifees-strategic-plan-101707.ppt and http://www.ifees.net/publications/documents/ifees-strategic-plan-101707.pdf

5. Indo-US Collaboration for Engineering Education (IUCEE). http://www.iucee.org

6. Indo-US Engineering Faculty Leadership Institute, Mysore, India, 26 May - 18 July 2008. http://www.ifees.net/documents/IUCEE_Leadership_Institute_Brochure.pdf

7. Paris Declaration: Inaugural Statement of the Global Engineering Deans Council. http://www.ifees.net/documents/GEDC_Brochure.pdf

8. Global Engineering Deans Council (GEDC) Leadership Institute Workshop. Boston, Massachusetts, 21 March 2009. http://www.ifees.net/calendar/index.cfm

9. Students Platform for Engineering Education Development. http://www.worldspeed.org

10. $5^{\text {th }}$ Global Students Forum on Engineering Education, St. Petersburg, Russia, May 15-23, 2009. http://www.ifees.net/news/index.cfm\#070109

11. Bhushan H. Trivedi and Maria M. Larrondo Petrie, "Beginning to Apply IUCEE Effective Teaching Strategies in India: An Experience in a Master of Computer Applications Program," in Proceedings of the $116^{\text {th }}$ Annual American Society for Engineering Education Conference and Exposition (ASEE2008), Austin, Texas, USA, June 14-17, 2009.

12. Paris Declaration Inaugural Statement of the Global Engineering Deans Council http://www.ifees.net/documents/GEDC_Brochure.pdf

13. 2009 IFEES Global Engineering Education Summit, St. Petersburg, Russia, May 19-23, 2009. http://www.ifees.net/activities/Summit.cfm

14. International Federation of Engineering Education Societies (IFEES). http://www.ifees.net 
Appendix A

\begin{tabular}{|c|c|}
\hline & IFEES Member Societies \\
\hline ACOFI & Colombian Engineering Education Society \\
\hline AEEA & African Engineering Education Association \\
\hline ANSTI & African Network of Science and Technical Institutions \\
\hline & Agilent Technologies, India \\
\hline ASEE & American Society for Engineering Education \\
\hline ASEAN & Association of South East Asian Nations Deans Steering Committee \\
\hline ASIBEI & Ibero-American Association of Engineering Institutes \\
\hline ASIIN & German Accreditation Agency for Natural Sciences and Mathematics \\
\hline ANFEI & Mexican Engineering Education Society \\
\hline ABENGE & Brazilian Engineering Education Society \\
\hline AAEE & Australasian Association for Engineering Education \\
\hline & Autodesk \\
\hline BEST & Board of European Students of Technology \\
\hline & Boeing \\
\hline & Chinese Society for Engineering Education \\
\hline CONDEFI & Council of Deans of Engineering of Chile \\
\hline & Council of Engineering Deans of Thailand \\
\hline COPEC & Council of Research in Education and Sciences \\
\hline & Dassault Systemes \\
\hline & Engineers Canada/Canadian Engineering Accreditation Board \\
\hline ECSA & Engineering Council of South Africa \\
\hline ESW & Engineers for a Sustainable World \\
\hline ENAEE & European Network for Accreditation of Engineering Education \\
\hline & Hewlett Packard Company \\
\hline IACEE & International Association for Continuing Engineering Education \\
\hline IGIP & International Society for Engineering Education \\
\hline & Infosys Technologies \\
\hline ISEL & Instituto Superior de Engenharia de Lisboa - Portugal \\
\hline ISTE & Indian Society of Technical Education \\
\hline ISTEC & Ibero American Science and Technology Education Consortium \\
\hline IUCEE & Indo-US Collaboration for Engineering Education \\
\hline JEE & Journal of Engineering Education \\
\hline JSEE & Japanese Society for Engineering Education \\
\hline KSEE & Kazakhstan Society of Engineering Education \\
\hline KSEE & Korean Society of Engineering Education \\
\hline KSDET & Korean Society of Semiconductor Equipment and Technology \\
\hline LACCEI & Latin American and Caribbean Consortium of Engineering Institutions \\
\hline MDK & Turkish Engineering Deans Council \\
\hline & Nucleo de Decanos de Ingenieria de Venezuela \\
\hline RACEE & Russian Association for Continuing Engineering Education \\
\hline RAEE & Russian Association for Engineering Education \\
\hline $\mathrm{RCl}$ & Cartagena Network for Engineering \\
\hline SAE & SAE - Brasil \\
\hline & Scalable Network Technologies \\
\hline SEFI & European Society for Engineering Education \\
\hline
\end{tabular}




\begin{tabular}{|l|l|} 
SIEMENS & SIEMENS \\
\hline SPEED & Student Platform for Engineering Education Development \\
\hline & The Institution of Engineers, Singapore \\
\hline & The MathWorks \\
\hline & Union Mexicana de Asociaciones de Ingenieros \\
\hline UPE & Upsilon Pi Epsilon International Honor Society for the Computing Disciplines \\
\hline WFEO & World Federation of Engineering Organization, Capacity Building Committee \\
\hline
\end{tabular}

$\mathbb{0}$
$\stackrel{0}{0}$
$\mathbb{D}$
$\vec{\perp}$
$\vec{D}$
$\stackrel{D}{0}$
$\vec{\sigma}$ 